\title{
Genital schistosomiasis mansoni: tubal tumor and parietal peritoneum involvement diagnosed during laparoscopy
}

\author{
Esquistossomose mansônica genital: tumor de trompa e envolvimento \\ do peritônio parietal diagnosticados durante laparoscopia
}

\author{
José Roberto Lambertucci', Quésia Tamara Mirante Ferreira Villamil², \\ Daniela Savi ${ }^{3}$ and Ilveu Cosme Dias ${ }^{2}$
}

\begin{abstract}
Female genital schistosomiasis is not uncommon in endemic areas for schistosomiasis, but there are few reports in the Brazilian medical literature. Here, we describe the case of a 31-year-old woman with lower abdominal pain who was diagnosed as presenting a fallopian tube tumor caused by Manson's schistosomiasis. The diagnosis was delayed because her symptoms were considered nonspecific. Involvement of the parietal peritoneum of the ovarian fossa was observed during laparoscopy and confirmed by histological analysis. The left tube and the tumor were excised and schistosomiasis was treated with praziquantel. She presented a full recovery and options for future reproduction are under evaluation.
\end{abstract}

Key-words: Schistosomiasis. Fallopian tube. Genital schistosomiasis. Tumor. Schistosomiasis mansoni.

\section{RESUMO}

Esquistossomose genital feminina não é incomum em áreas endêmicas para esquistossomose, mas, há poucos relatos na literatura médica brasileira. Descrevemos aqui, o caso de uma paciente de 31 anos com dor abdominal no baixo ventre que recebeu o diagnóstico de tumor da trompa de falópio causada pela esquistossomose mansônica. 0 diagnóstico foi retardado porque os sintomas foram considerados inespecíficos. Havia envolvimento do peritônio parietal da fossa ovárica durante a laparoscopia, confirmado à histologia. A tuba esquerda e o tumor foram extirpados e a esquistossomose foi tratada com praziquantel. A paciente apresentou recuperação completa e opções para reprodução futura estão sob avaliação.

Palavras-chaves: Esquistossomose. Trompa de Falópio. Esquistossomose genital. Tumor. Esquistosomose mansoni.

There are several reports indicating that genital lesions in Schistosoma mansoni infection are not uncommon ${ }^{172} 13$. It has been estimated that 6 to $27 \%$ of girls and women with intestinal schistosomiasis suffer from pathological conditions induced by eggs sequestered somewhere in their genital organs. Female genital schistosomiasis is also often misdiagnosed as a sexually transmitted disease ${ }^{33}$. Recently, the World Health Organization decided to include female genital schistosomiasis in the group of gender-specific diseases that deserve high priority research.

Data on the topographic distribution of genital lesions reported from Brazil and other countries have shown the involvement of the following organs, ranked in descending order of importance: ovaries, cervix uteri, uterus, fallopian tubes, vulva and vagina ${ }^{1432}$. In

\footnotetext{
1. Graduation Course in Health Science, Infectology and Tropical Medicine, Faculty of Medicine, Federal University of Minas Gerais, Belo Horizonte, MG, Brazil. 2. Semper Hospital, Gynecology and Obstetrics Clinic, Belo Horizonte, MG,Brazil. 3. Semper Hospital, Pathology Department, Belo Horizonte, MG, Brazil.

Address to: Dr. José Roberto Lambertucci. Faculty of Medicine/UFMG. Av. Alfredo Balena 190, 30130-100 Belo Horizonte, MG, Brazil.

Tel: $55313409-9820$

e-mail: lamber@uai.com.br

Received in 04/05/2009

Accepted in 15/09/2009
}

contrast with infections due to Schistosoma haematobium, there are few data concerning Schistosoma mansoni-induced genital lesions. In Brazil, the literature abounded with case reports in the 1940 s and 1950 s, i.e. during the period when schistosomiasis received considerable scientific and public health attention for the first time. Thereafter, there was almost total silence in the literature in relation to this subject, but it seems to have again been attracting increasing attention more recently ${ }^{62252829}$.

Genital schistosomiasis has been explained in terms of worm migration and embolization of passively transported eggs to vessels of this anatomical region. Evidence of migrating worms is clearly demonstrated by identifying copulating adult worms in histological sections from internal genital organs ${ }^{13}$.

In a prospective study, Bland and Geldand ${ }^{5}$ reported that 10 patients out of 104 from a country endemic for bilharzia showed definite evidence of bilharziasis in the fallopian tubes. The importance of schistosomiasis of the fallopian tubes is that it may predispose toward ectopic pregnancy and decreased fertility $y^{46112030}$. Armbrust $^{2}$ described a case in Brazil in which Schistosoma mansoni had caused severe tubal disease.

Here, we add another case of a patient with a tubal tumor and peritoneal involvement caused by Manson's schistosomiasis diagnosed during laparoscopy. 


\section{CASE REPORT}

A 31-year-old woman came to the hospital complaining of lower abdominal discomfort and hyporexia, which had started two months earlier. She had been using nonsteroidal anti-inflammatory agents for pain with partial relief. She visited three physicians during this period and was assured that her symptoms had no organic basis or explanation. In our hospital, a gynecological examination revealed tenderness during mobilization of the uterus and palpation of the left adnexus. There was no fever or tachycardia on admission. No pelvic or abdominal masses were palpable. Laboratory tests were negative for $\mathrm{hCG}$ and normal for C-reactive protein, erythrocyte sedimentation rate, urine culture, hemogram and leukocyte count. Pelvic ultrasound showed a hypoechoic homogeneous mass of $3 \mathrm{~cm}^{3}$ in the left paraovarian area. The uterus and ovaries were normal. With a probable diagnosis of tubo-ovarian abscess, she was treated for pelvic inflammatory disease with antibiotics (clindamycin and gentamicin). She improved over the next 24 hours but abdominal discomfort recurred thereafter. New laboratory tests did not help. However, another ultrasound revealed a larger adnexal mass of $22 \mathrm{~cm}^{3}$ (Figure 1). During laparoscopy, a hard blackish tumoral mass containing blood with whitish spots, with a largest diameter of $4 \mathrm{~cm}$, was observed (Figure 2). This mass adhered to the left

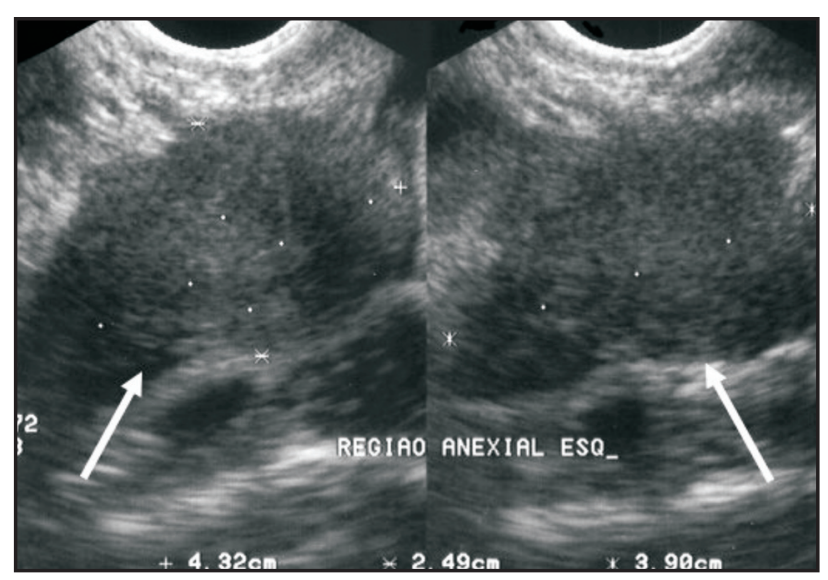

FIGURE 1

Ultrasound: a tumoral mass in the left adnexa (white arrows).

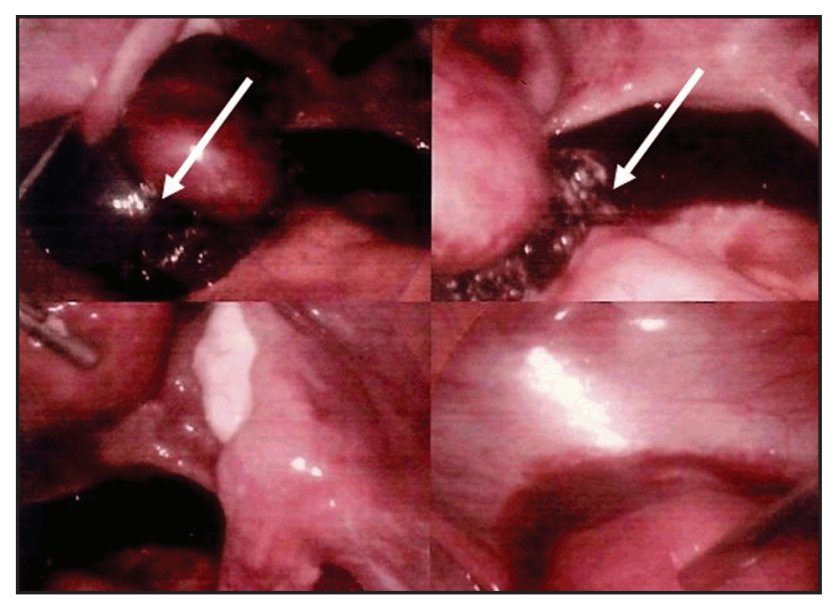

FIGURE 2

Laparoscopy: tumoral mass in left tube (arrows). fallopian tube, which was edematous and twisted. Both ovaries were normal. In both ovarian fossae, the peritoneum showed whitish granules (Figure 3). With a presumptive diagnosis of tubal pregnancy, the left tube and ovary were excised together with the tumoral mass. Biopsies of the ovarian fossae were also taken. She improved quickly after the procedure and was discharged from hospital two days later. Histological examination of the surgical material revealed the presence of Schistosoma mansoni eggs in the tumoral mass (Figure 4), uterine tube (with salpingitis) and ovarian fossae (Figure 5). Ultrasound of the liver did not reveal any evidence of schistosomal liver fibrosis or signs of portal hypertension. Stool examination and rectal biopsy resulted negative for Schistosoma mansoni eggs. One month later, she was treated for schistosomiasis with praziquantel $(50 \mathrm{mg} / \mathrm{kg}$ of body weight, in a single dose). She is being followed up at the outpatient clinic and, over the initial six months after hospital discharge, has had no further complaints.

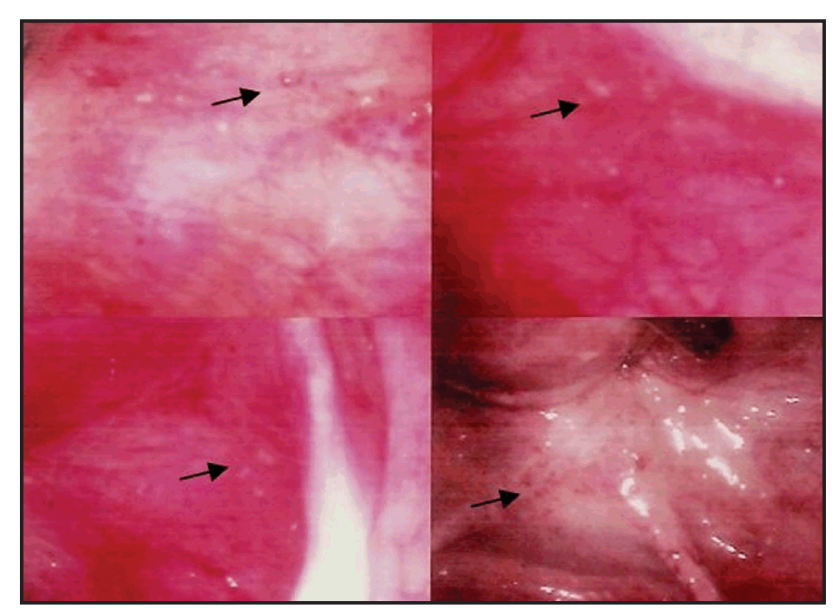

FIGURE 3

Laparoscopy: ovarian fossa with granules (arrows).

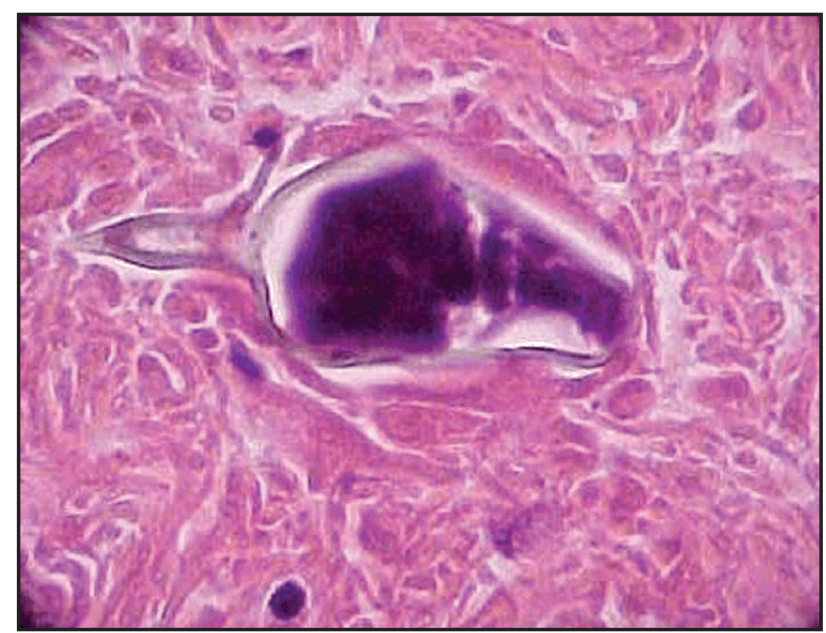

FIGURE 4

A Schistosoma mansoni egg in the left fallopian tube. 


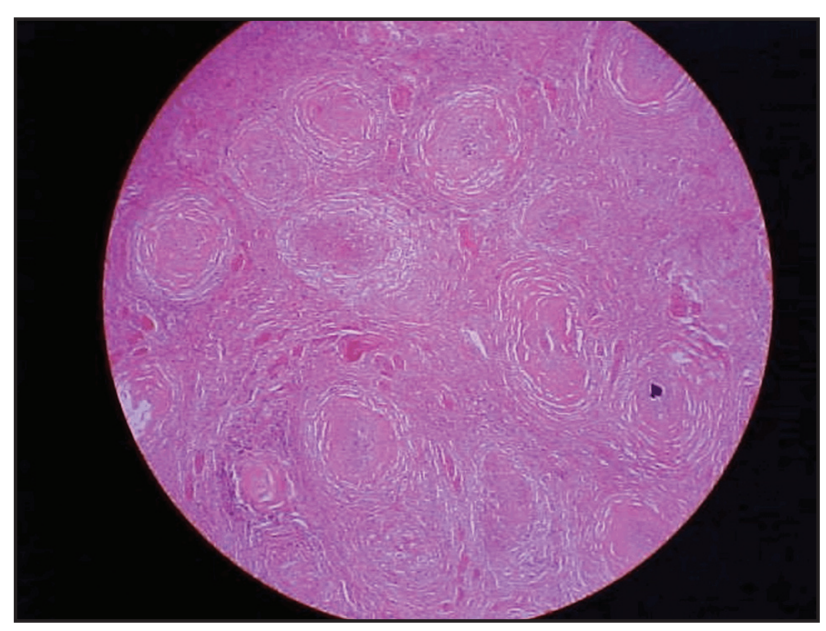

FIGURE 5

Granulomas in the peritoneum of the left ovarian fossa.

\section{DISCUSSION}

It took some time for physicians to investigate the hypogastric pain of this patient. She was anxious because her marriage was due to take place six months after the symptoms started. Anxiety was her first diagnosis. After genital schistosomiasis was diagnosed and treated with praziquantel, she was worried about her chances of having a baby because she had lost the left tube and schistosomiasis had spread to the right ovarian fossa. This patient was referred to a reproductive endocrinology clinic to discuss her options for future fertility. Infertility and ectopic pregnancy are real threats to such patients and have been acknowledged by investigators since the time of the first case descriptions ${ }^{4810151635}$.

In a recent review of 83 cases of genital Manson's schistosomiasis, it was observed that the ovaries were the main organs affected $(28 / 83 ; 33 \%)$, followed by the cervix $(20 / 83$; $25 \%)$, fallopian tubes $(14 / 83 ; 17 \%)$, uterus $(15 / 83 ; 18 \%)$ and vulva $(5 / 83 ; 6 \%)^{12} 2627$. The primary involvement in our patient was in the left fallopian tube, but it is worth bearing in mind that granuloma had spread to the parietal peritoneum in this area. No worms were found in the vessels, but eggs of Schistosoma mansoni with and without granuloma formation were readily encountered, particularly in the ovarian fossa (Figure 5). The presence of worms in the genital area, including the skin, has been described both in male and in female patients ${ }^{23671415253034}$.

Stool examination and rectal biopsy did not reveal any worm eggs in our patient. Such findings have been reported previously and this reinforces the need to maintain a high index of suspicion of schistosomiasis among patients who live in endemic areas or have recently traveled to endemic areas ${ }^{182126}$. In our case, it was impossible to assess whether the schistosomiasis had been cured after treatment with praziquantel because stool examination and rectal biopsy were of no use for diagnosis.

The second ultrasound performed on our patient suggested the presence of an ovarian abscess. Ovarian abscesses are associated with pelvic inflammatory diseases caused by bacteria.
The clinical picture frequently includes the presence of fever and laboratory abnormalities (leukocytosis and C-reactive protein augmentation in serum), but our patient had no evidence of bacterial infection ${ }^{19} 24$.

The numbers of descriptions of cases of genital schistosomiasis in Brazil declined from the 1960s onwards. No sound explanation for this has been offered so far. However, it is well known that before the start of the Brazilian Program for Schistosomiasis Control in the 1970s, Brazilian scientists and the Ministry of Health decided that hepatosplenic schistosomiasis should be considered to be the most severe form of Manson's schistosomiasis. Thus, diminishing or eliminating this form of the disease was the main priority of the control program ${ }^{920}$. Many aspects of the disease, such as neuroschistosomiasis, glomerulonephritis, pulmonary hypertension, liver abscess, acute schistosomiasis and Salmonella bacteremia, among others, were left aside ${ }^{172123}$. It is possible that genital involvement may have also been neglected.

The patient in the present study did not have any periportal fibrosis (as investigated by ultrasound) or any evidence of portal hypertension. Hence, she had hepatointestinal schistosomiasis and severe disease of the genital organs. Fortunately, the Brazilian Ministry of Health has changed its view about the disease and, at the latest meeting of the Schistosomiasis Control Committee, it was decided to encourage healthcare personnel to evaluate and report on the neglected aspects of this disease.

Summing up, we have presented here the case of a patient with tubal and peritoneal Manson's schistosomiasis who, over a twomonth period, evolved with vague pain in the lower abdomen that represented a diagnostic challenge for the attending physicians. The left fallopian tube was excised and schistosomiasis was treated with praziquantel. Healthcare personnel should be aware of this condition and look for a diagnosis of genital schistosomiasis among patients from endemic areas.

\section{REFERENCES}

1. Arean VM. Manson's schistosomiasis of the female genital tract. American Journal of Obstetrics and Gynecology 72: 1038-1053, 1956.

2. Armhurst AF. Genito-urinary lesions in Schistosoma mansoni. O Hospital 38: 176-210, 1950.

3. Bambirra EA, Andrade JS, Bamberg A, Souza EA, Mitidiero CE, Souza AF. Testicular schistosomiasis mansoni: a differential diagnostic problem with testicular neoplasias. The American Journal of Tropical Medicine and Hygiene 35:791-792, 1986.

4. Bahrami S, Alatassi H, Slone SP O'Connor DM. Tubal gestation and schistosomiasis. Journal of Reproductive Medicine 51: 595-598, 2006.

5. Bland KG, Gelfand MG. The effects of schistosomiasis on the Fallopian tubes in the African female. The Journal of Obstetrics and Gynaecology 77: 1024-1027, 1970.

6. Cabral ACV, MirandaS, Monteiro JB. Associação entre salpingite esquistossomótica e gravidez ectópica. Relato de um caso. Jornal Brasileiro de Ginecologia 102: 27-28, 1992.

7. Câmara A. Esquistossomose genital feminina. Revista de Ginecologia e D’Obstetrícia 3: 271-280, 1959.

8. Charlewood GP, Shippel S, Renton H. Schistosomiasis in gynaecology. Journal of Obstetrics and Gynaecology 56: 367-385, 1949. 
9. Drummond SC, Silva LC, Amaral RS, Sousa-Pereira Sr, Antunes CM, Lambertucci JR. Morbidity of schistosomiasis mansoni in the state of Minas Gerais, Brazil. Memórias do Instituto Oswaldo Cruz 101: 37-44, 2006.

10. El-Mahgoub S. Pelvic schistosomiasis and infertility. International Journal of Gynaecology and Obstetrics 20: 201-206, 1982.

11. Eogan M, O`Malley A, Flavin R, Gillan J McKenna P, Coulter-Smith S. Ectopic pregnancy associated with tubal schistosomiasis. Irish Medical Journal 95: 250, 2002.

12. Feldmeier H, Daccal RC, Martins MJ, Soares V, Martins R. Genital manifestations of schistosomiasis mansoni in women: important but neglected. Memórias do Instituto Oswaldo Cruz 93: 127-133, 1998.

13. Froes AGC 1957. Contribuição ao estudo da esquistossomose nos genitais femininos. Arquivos de Oncologia 2: 37-50, 1957.

14. Gelfand M, Ross MD, Blair DM, Castle WM, Weber MC. Schistosomiasis of the male pelvic organs. Severity of infection as determined by digestion of tissue and histologic methods in 300 cadavers. The American Journal of Tropical Medicine and Hygiene 19: 779-784, 1970

15. Gelfand M, Ross MD, Blair DM, Weber MC. Distribution and extent of schistosomiasis in female pelvic organs, with special reference to the genital tract, as determined at autopsy. The American Journal of Tropical Medicine and Hygiene 20: 846-849, 1971.

16. Hoffman $\mathrm{H}$, Bauerfeind I. High tissue egg burden mechanically impairing the tubal motility in genital schistosomiasis of the female. Acta Obstetricia et Gynecologica Scandinavica 82: 970-971, 2003.

17. LambertucciJR. Acute schistosomiasis: clinical, diagnostic and therapeutic features. Revista do Instituto de Medicina Tropical de São Paulo 35: 399-404, 1993.

18. Lambertucci JR. Schistosoma mansoni: pathological and clinical aspects. In: Jordan P and Webbe G (eds.) Human Schistosomiasis. Cab International, Wallingford, UK, pp. 195-235, 1993

19. Lambertucci JR, Rayes AA, Serufo JC, Nobre V. Pyogenic abscesses and parasitic diseases. Revista do Instituto de Medicina Tropical de São Paulo 43: 67-74, 2001.

20. Lambertucci JR, Rocha RS, Carvalho OS, Katz N. A esquistossomose mansoni em Minas Gerais. Revista da Sociedade Brasileira de Medicina Tropical 20: 47-52, 1987.

21. Lambertucci JR, Serufo JC, Gerspacher-Lara R, Rayes AAM, Teixeira R, Nobre V, Antunes CMF. Schistosoma mansoni: assessment of morbidity before and after control. Acta Tropica 77: 101-109, 2000
22. Lambertucci JR, Silva LCS, Andrade LM, Queiroz LC, Carvalho VT, Voieta I, Antunes CM. Imaging techniques in the evaluation of morbidity in schistosomiasis mansoni. Acta Tropica 108: 209-217, 2008

23. Lambertucci JR, Silva LC, Amaral RS. Guidelines for the diagnosis and treatment of schistosomal myeloradiculopathy. Revista da Sociedade Brasileira de Medicina Tropical 40: 574-581, 2007.

24. Lambertucci JR, Teixeira R, Navarro MM, Coelho PMZ, Ferreira MD. Liver abscess and schistosomiasis. A new association. Revista da Sociedade Brasileira de Medicina Tropical 23: 239-240, 1990.

25. Lambertucci JR, Voieta I, Barbosa AJ. Schistosomiasis mansoni of the prostate Revista da Sociedade Brasileira de Medicina Tropical 39: 233-234, 2006

26. Lambertucci JR, Voieta I, De Brot M. Vulvar schistosomiasis mansoni. Revista da Sociedade Brasileira de Medicina Tropical 41: 435-436, 2008.

27. Landry P, Favrat B, Raeber PA. Genital schistosomiasis after a missed diagnosis of Katayama syndrome. Journal of Travel Medicine 4: 237-238, 1996.

28. Oliveira CAB, Aquino A, Simon EF, Eyer-Silva WA. Concomitant prostatic schistosomiasis and adenocarcinoma: case report and review. The Brazilian Journal of Infectious Diseases 6: 45-49, 2002.

29. Poderoso WLS, Santana WB, Costa EF, Cipolotti R, Fakhouri R. Ectopic schistosomiasis: description of five cases involving skin, one ovarian case and one adrenal case. Revista da Sociedade Brasileira de Medicina Tropical 41: 668-671, 2008

30. Ramos SF. Late cutaneous bilharziasis. South African Medical Journal 47: 2103-2108, 1973.

31. Rosen Y, Kim B. Tubal gestation associated with Schistosoma mansoni salpingitis Obstetrics and Gynecology 43: 413-417, 1974.

32. Seif-Eldin D. Bilharziasis of the fallopian tubes and ovaries. Journal of Obstetrics and Gynaecology 65: 457-459, 1958

33. Sheorey H, Charles PGP, Pyman J. Ectopic schistosomiasis in a returned traveler. Journal of Travel Medicine 11: 251-251, 2004.

34. Swai B, Poggensee G, Mtweve S, Krantz I. Female genital schistosomiasis as an evidence of a neglected cause for reproductive ill-health: a retrospective histopathological study from Tanzania. BMC Infectious Diseases 6: 134-141, 2006

35. Ville Y, Leruez M, Picaud A, Walter P, Fernandez H. Tubal schistosomiasis as a cause of ectopic pregnancy in endemic areas: a report of three cases. European Journal of Obstetrics and Gynecology and Reproductive Biology 42: 77-79, 1991. 